\title{
Treatment of chronic urinary tract infections with gentamicin
}

\author{
A. A. LINDBERG, H. BUCHT, AND L. O. KALLINGS \\ From the National Bacteriological Laboratory, Stockholm, and the Renal Clinic, St. Erik's \\ Hospital, Stockholm
}

SYNOPSIS Gentamicin was of value in the treatment of chronic urinary tract infections caused by multiresistant bacterial strains for which no atoxic antibiotic was available. The treatment was carried out after alkalinization of the patient's urine. With the dosage given, gentamicin gave a low serum and a relatively high urine concentration. Excretion of active gentamicin in the urine was high even in patients with impaired renal function. The results of treatment of complicated chronic urinary tract infections with initial gentamicin and following long-term therapy showed negative urinary cultures in 12 out of 24 patients within one to 14 months of follow-up time. To reduce the risk of toxic side effects the dosage was adjusted according to the patient's kidney function. No development of resistance was demonstrated in the bacteria.

Chronic urinary tract infections caused by various Gram-negative bacteria pose an ever-increasing problem from the point of view of treatment. These bacteria are often naturally resistant to many antibiotics or have developed resistance against sulphonamides, penicillins, streptomycin, tetracyclines, chloramphenicol, and nitrofurantoin. The antibiotics which remain for treatment are, for example, kanamycin, neomycin, polymyxin $\mathrm{B}$, and colistin. However, these antibiotics are potentially neuro-, oto-, or nephrotoxic, particularly when not given in reduced doses to patients with an underlying kidney disease. This report describes our experience in the treatment of chronic urinary tract infections with a new antibiotic, gentamicin. The drug had not been used in Sweden before.

Gentamicin is a mixture of antibiotics which are obtained from Micromonosporea purpurea (Luedemann and Brodsky, 1963). Gentamicin is related in its activity to streptomycin, kanamycin, and neomycin (Rosselet, Marquez, Meseck, Murawski, Hamdan, Joyner, Schmidt, Migliore, and Herzog, 1963; Weinstein, Luedemann, Oden, and Wagman, 1963a; Weinstein, Luedemann, Oden, Wagman, Rosselet, Marquez, Coniglio, Charney, Herzog, and Black, 1963b). The absorption from the gastrointestinal tract is poor and therefore it must be administered parenterally; $25 \%$ to $30 \%$ is bound to serum albumin (Black, Calesnick, Williams, and Weinstein, 1963;

Received for publication 29 March 1967
Bulger, Sidell, and Kirby, 1963). In vitro investigations showed that gentamicin had a bactericidal effect against various Gram-negative bacteria and Staphylococus aureus (Black et al., 1963; Rubenis, Kozij, and Jackson, 1963; Weinstein et al., 1963a, b). Clinical investigations showed that gentamicin was effective in the treatment of urinary tract infections caused by a number of different Gram-negative bacteria (Bulger et al., 1963; Jao and Jackson, 1963; Klein, Eickhoff, and Finland, 1964). Toxic side effects on the vestibular function with permanent labyrinth injury was observed when relatively large doses were used for the treatment of patients with reduced kidney function (Bulger et al., 1963; Jao and Jackson, 1963).

In this study the results of the treatment of 25 patients with varying degrees of impaired kidney function are reported where gentamicin was used in a reduced dosage. In addition to these clinical tests its in vitro activity against 338 bacterial strains was investigated.

\section{MATERIAL AND METHODS}

ANTIBACTERIAL ACTIVITY Minimal inhibitory concentrations (M.I.C.) and minimal bactericidal concentrations (M.B.C.) were determined by the tube dilution method against newly isolated strains of pathogenic bacteria. Of a $10^{-4}$ dilution of an 18 -hour culture, $0.5 \mathrm{ml}$., representing 1-2 $\times 10^{5}$ bacteria, was pipetted into a series of tubes with $0.5 \mathrm{ml}$. gentamicin in phosphate-buffered brain 


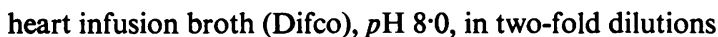
from $0.3 \mu \mathrm{g} . / \mathrm{ml}$. to $40 \mu \mathrm{g} . / \mathrm{ml}$. The tubes were incubated at $37^{\circ} \mathrm{C}$., read after 18 hours, shaken, and read again after 24 hours. The lowest concentration of gentamicin which gave inhibition of bacterial growth was determined as the M.I.C. The M.B.C. was determined by subcultivation from the tubes showing no bacterial growth to blood agar plates and reading the lowest concentration of gentamicin from which no bacteria could grow after incubation overnight.

The M.I.C. and M.B.C. values for kanamycin and colistin were determined in the same manner.

The gentamicin activity at varying $p \mathrm{H}$ was investigated

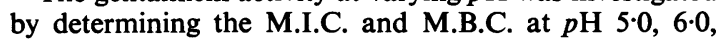
$7 \cdot 0$, and $8 \cdot 0$.

SERUM AND URINE CONCENTRATION Gentamicin ${ }^{1}$ for parenteral use was supplied in a concentration of $30 \mathrm{mg}$. $/ \mathrm{ml}$., and was injected intramuscularly twice daily at 12 -hour intervals for seven days. Blood samples were taken on the first day one hour after the second dose. During the third day of treatment blood and urine samples were taken at one, four, eight, and 12 hours after the first dose and all urine was collected between the times of sampling. During the fifth day a total 24-hour urine sample was collected. Two blood samples were taken two and seven days after the treatment was concluded. The serum and urine were stored at minus $20^{\circ} \mathrm{C}$. until the antibiotic concentration was determined using an agar-diffusion assay (Oden, Stander, and Weinstein, 1963) employing Bacillus subtilis (A.T.C.C. 6633) or Staphylococcus albus, $\mathrm{KL}^{2}$ ) as the test organism.

CLINICAL STUDIES Twenty-five patients representing different grades of reduced kidney function from St. Erik's and Danderyd's Hospitals, Stockholm, were treated. All patients except one had chronic pyelonephritis (see Table III) with bacteriuria (more than $10^{5}$ bacteria per ml. urine). The number of bacteria was determined by quantitative cultivation technique. In vitro sensitivity against gentamicin and other antibiotics was investigated before treatment. Before gentamicin therapy most of the patients had been treated with a number of antibiotics without prolonged freedom from bacteriuria. The dose of gentamicin administered was based upon bodyweight and kidney function measured as the endogenous creatinine clearance. Before treatment, the patient's urine was made alkaline; the $p \mathrm{H}$ was tested daily during treatment and

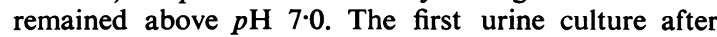
initiation of therapy was taken on the second to fourth day, and then when the gentamicin therapy was concluded. Thereafter the patients were followed up by urine cultivations every month.

The patients were carefully observed for toxic side effects. Before and after gentamicin therapy they were examined by Dr. J. Wersäll of the otological clinic, the Karolinska Hospital, with special concern for vestibular function.

${ }^{1}$ By courtesy of the Schering Corp., Bloomfield, New Jersey.

'Kindly supplied by Dr. K. Lincoln, Göteborg.
TABLE I

SUSCEPTIBILITY OF PATHOGENIC BACTERIA TO GENTAMICIN IN VITRO

\begin{tabular}{lccc} 
Organism & $\begin{array}{c}\text { No. of } \\
\text { Strains }\end{array}$ & $\begin{array}{c}\text { Concentration of } \\
\text { Gentamicin }(\boldsymbol{\mu g} . / \mathrm{ml} .)\end{array}$ \\
\cline { 3 - 4 } & & $\begin{array}{c}\text { Range } \\
\text { Median }\end{array}$ \\
\cline { 3 - 4 } & & M.I.C. & M.B.C. \\
\hline E. coli & 56 & $\frac{0 \cdot 3-10}{2 \cdot 0}$ & $\frac{0 \cdot 6-10}{2 \cdot 7}$ \\
Klebsiella sp. & 110 & $\frac{0 \cdot 3-5}{0 \cdot 8}$ & $\frac{0 \cdot 6-20}{2 \cdot 6}$ \\
Proteus mirabilis & 24 & $\frac{0 \cdot 3-5}{2 \cdot 2}$ & $\frac{0 \cdot 6-40}{5 \cdot 7}$ \\
Proteus sp. indole-positive & 8 & $\frac{1 \cdot 25-2 \cdot 5}{2 \cdot 0}$ & $\frac{1 \cdot 25-10}{5 \cdot 0}$ \\
Ps. aeruginosa & 106 & $\frac{0 \cdot 3-5}{0 \cdot 8}$ & $\frac{0 \cdot 6-40}{4 \cdot 0}$ \\
Staphylococcus aureus & 36 & $\frac{0 \cdot 1-0 \cdot 6}{0 \cdot 4}$ & $\frac{0 \cdot 6-5}{2 \cdot 0}$
\end{tabular}

RESULTS

ANTIBACTERIAL ACTIVITY The M.I.C. and M.B.C. values of gentamicin at $p \mathrm{H} 8.0$ for 302 Gramnegative bacteria and 36 strains of Staphylococcus aureus are shown in Table I. A concentration of 1.2 $\mu \mathrm{g}$. gentamicin $/ \mathrm{ml}$. inhibited $100 \%$ of Staphylococcus aureus, $96 \%$ of Klebsiella, $93 \%$ of Pseudomonas, $62 \%$ of E. coli, and $37 \%$ of Proteus species. Five $\mu \mathrm{g}$. gentamicin $/ \mathrm{ml}$. had a bactericidal effect on $100 \%$ of Staphylococcus aureus, $86 \%$ of Klebsiella, $89 \%$ of Pseudomonas, $94 \%$ of $E$. coli, and on $73 \%$ of the strains of Proteus species.

COMPARISON BETWEEN IN VITRO ACTIVITY OF GENTAMICIN, KANAMYCIN AND COLISTIN Eighty-five Gramnegative strains were chosen from the above mentioned material for comparison of the antibacterial effect of gentamicin with kanamycin and colistin. All strains were isolated from patients with infections which were difficult to treat. Table II shows the M.I.C. and M.B.C. values obtained. Inhibition of bacterial growth occurred with lower concentrations of gentamicin than with kanamycin or colistin, with the exception that $E$. coli strains were inhibited by a lower concentration of colistin. Lower concentrations of kanamycin and colistin than of gentamicin were required to produce a bactericidal effect on Klebsiella strains. Gentamicin had the best in vitro bactericidal effect against Pseudomonas and Proteus species.

EFFECT OF VARYING $p H$ ON THE ANTIBACTERIAL ACTIVITY OF GENTAMICIN The effect of different $p H$ on the M.I.C. and M.B.C. values for gentamicin was determined on three strains-Klebsiella, Proteus mirabilis, and Pseudomonas aeruginosa. Figure 1 shows that the $p H$ value was of decisive importance 
TABLE II

SUSCEPTIBILITY OF PATHOGENIC BACTERIA TO GENTAMICIN, KANAMYCIN, AND COLIMYCIN IN VITRO

\begin{tabular}{|c|c|c|c|c|c|c|c|}
\hline \multirow[t]{4}{*}{ Organism } & \multirow{4}{*}{$\begin{array}{l}\text { No. of } \\
\text { Strains }\end{array}$} & \multirow{2}{*}{\multicolumn{2}{|c|}{ Concentration in $\mu \mathrm{g} . / \mathrm{ml}$. }} & \multirow{2}{*}{\multicolumn{4}{|c|}{$\frac{\text { Range }}{\text { Median }}$}} \\
\hline & & & & & & & \\
\hline & & \multicolumn{2}{|c|}{ Gentamicin } & \multicolumn{2}{|c|}{ Kanamycin } & \multicolumn{2}{|l|}{ Colistin } \\
\hline & & M.I.C. & M.B.C. & M.I.C. & M.B.C. & M.I.C. & M.B.C. \\
\hline \multirow{2}{*}{ E. Coli } & \multirow{2}{*}{13} & $0 \cdot 6-2 \cdot 5$ & $1 \cdot 25-5 \cdot 0$ & $\underline{1 \cdot 25-20}$ & $2 \cdot 5-20$ & $0 \cdot 6-1 \cdot 25$ & $0 \cdot 6-2 \cdot 5$ \\
\hline & & $1 \cdot 1$ & $2 \cdot 0$ & $3 \cdot 2$ & 5.0 & 0.8 & 1.0 \\
\hline \multirow[t]{2}{*}{ Klebsiella sp. } & \multirow[t]{2}{*}{19} & $\underline{0.6-5 \cdot 0}$ & $\underline{0 \cdot 6-20}$ & $\underline{0 \cdot 6-20}$ & $\underline{0 \cdot 6-20}$ & $\underline{0.6-20}$ & $\underline{0.6-20}$ \\
\hline & & $\begin{array}{c}1 \cdot 5 \\
0 \cdot 6-10\end{array}$ & $\begin{array}{c}5 \cdot 2 \\
0 \cdot 6-20\end{array}$ & $\begin{array}{c}2 \cdot 4 \\
0 \cdot 6-20\end{array}$ & $\begin{array}{c}3 \cdot 0 \\
0 \cdot 6-20\end{array}$ & $\begin{array}{c}3 \cdot 1 \\
>20\end{array}$ & $\begin{array}{c}3 \cdot 5 \\
>20\end{array}$ \\
\hline Proteus sp. & 15 & $\overline{2 \cdot 7}$ & $\overline{6.4}$ & $\overline{4.3}$ & $\overline{10}$ & - & -20 \\
\hline \multirow{2}{*}{ Ps. aeruginosa } & \multirow{2}{*}{38} & $0 \cdot 6-5 \cdot 0$ & $0 \cdot 6-20$ & $5 \cdot>20$ & $20->20$ & $\begin{array}{r}>20 \\
0 \cdot 6-20\end{array}$ & $\begin{array}{c}>20 \\
0 \cdot 6->20\end{array}$ \\
\hline & & $1 \cdot 0$ & $5 \cdot 6$ & $>20$ & $>20$ & $7 \cdot 8$ & $>20$ \\
\hline
\end{tabular}

TABLE III

RELEVANT DATA IN 25 PATIENTS WITH PYELONEPHRITIS TREATED WITH GENTAMICIN

$\begin{array}{lll}\text { Case } & \text { Age } & \text { Diagnosis } \\ \text { No. } & \text { and } & \\ & \text { Sex }\end{array}$

$\begin{array}{llll}\begin{array}{l}\text { Endo- } \\ \text { genous }\end{array} & \begin{array}{l}\text { Infecting } \\ \text { Organism }\end{array} & \begin{array}{l}\text { M.I.C. }{ }^{2} \\ (\mu \mathrm{g} . / \mathrm{ml} .)\end{array} & \begin{array}{l}\text { M.B.C. }{ }^{3} \\ (\mu \mathrm{g} . / \mathrm{ml} .)\end{array} \\ \begin{array}{l}\text { Creatinine } \\ \text { Clearance }\end{array} & & & \\ \text { (ml.min }) & & \end{array}$

Gentamicin

mg./kg. Total Long-term Follow-up Relapse of

Clearance
$($ ml./min. $)$ $\begin{array}{llll}\text { Body- Dose (g.) Therapy } & \text { (mth.) } & \text { Bacteriuria } & \end{array}$ weight and

Day

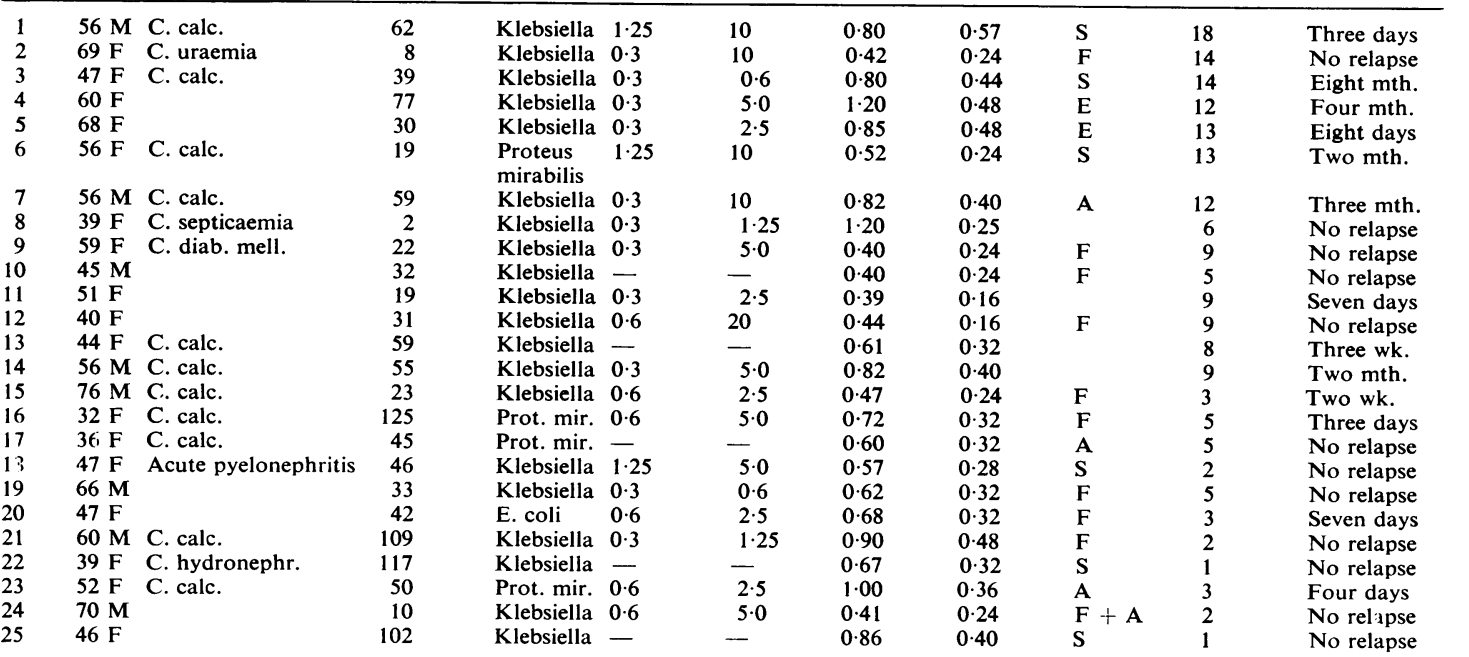

${ }^{1}$ All patients except no. 18 had chronic pyelonephritis. In this column the complications are listed. C. calc. $=$ calculus formation in one or both kidneys.

${ }^{2}$ M.I.C. = minimum inhibiting concentration of gentamicin

${ }^{3}$ M.B.C. = minimum bactericidal concentration of gentamicin

${ }^{4} \mathrm{~S}=$ sulphonamides

$\mathrm{F} \quad=$ nitrofurantoin

A $\quad=$ acidifying agents

$\mathrm{E} \quad=$ erythromycin

${ }^{5}$ Period before positive urine cultures were again detected.

for the activity of gentamicin. The concentration of gentamicin required to inhibit or kill the Klebsiella and Pseudomonas strains at $p \mathrm{H} 5$ was 15 to 30 times higher than at $p \mathrm{H} 8$, and 30 times higher to inhibit the Proteus mirabilis strains at $p \mathrm{H} 6$ than at $p \mathrm{H} 8$.

patients (Table III) were divided into three groups with regard to kidney function measured by endogenous creatinine clearance. Group I comprised patients with an endogenous creatinine clearance greater than $60 \mathrm{ml} . / \mathrm{min}$., representing a normal or moderately reduced kidney function. Patients in group II had clearance values of 20 to $60 \mathrm{ml} . / \mathrm{min}$., 


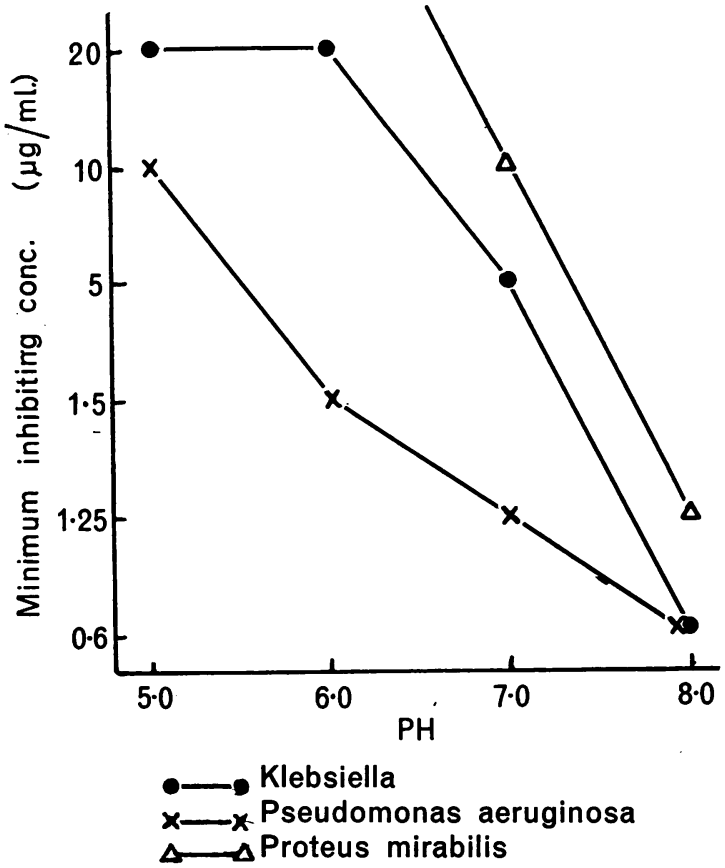

FIG. 1. Susceptibility of three different organisms to gentamicin at different $\mathrm{pH}$ values. representing a marked reduction of kidney function (the majority of patients were within this group). Group III represented patients with serious kidney insufficiency having an endogenous creatinine clearance of less than $20 \mathrm{ml} . / \mathrm{min}$. The dose of gentamicin was chosen individually with regard to the patient's kidney function. Patients in group I received $0 \cdot 7-1 \cdot 2 \mathrm{mg}$. gentamicin $/ \mathrm{kg}$. bodyweight per day, patients in group II received 0.4-1.0 mg., and patients in group III received $0 \cdot 4-0.5 \mathrm{mg}$. with one exception (case 8). The gentamicin dose was doubled during the first day of treatment.

The highest concentration in serum was obtained in the one-hour specimens, and the maximum concentration found was $6.4 \mu \mathrm{g} . / \mathrm{ml}$. (case 24). However, the majority of the one-hour values were approximately 2-3 $\mu \mathrm{g}$. $/ \mathrm{ml}$. (Fig. 2). Four hours after injection the patients in group III had the highest values of 3.8 and $2.9 \mu \mathrm{g} . / \mathrm{ml}$. while the patients in group I with the best kidney function reached a value of only $1.5 \mu \mathrm{g} . / \mathrm{ml}$. in spite of a larger dose. The same tendency was apparent in the eight- and 12-hour values, the maximum concentration measured was 3.6 and $2.5 \mu \mathrm{g} . / \mathrm{ml}$., respectively. With the majority of patients the eight- and 12-hour values of gentamicin were very low, approximately $1 \mu \mathrm{g}$. $/ \mathrm{ml}$. serum.

CONCENTRATION OF GENTAMICIN IN URINE In most patients the maximum concentration of biologically

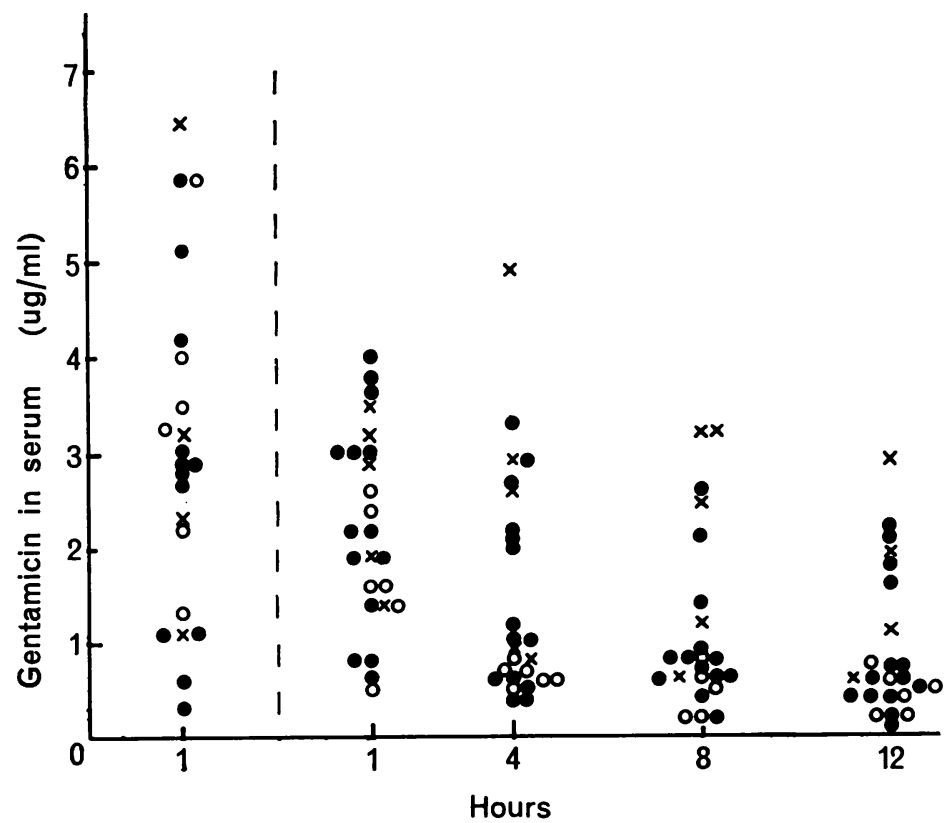

FIG. 2. Levels of gentamicin in serum during treatment. Gentamicin was injected at 0 and 12 hours. The first one-hour specimen was taken on the first day of treatment after a double dose o, gentamicin. The following serum levels were measured on the third day of treatment. $\bigcirc-\bigcirc$ patients with an endogenous creatinine clearance above $60 \mathrm{ml}$. per min.; - clearance value 20 to $60 \mathrm{ml}$. per min.; $\times-\times$ clearance value less than $20 \mathrm{ml}$. per min. 


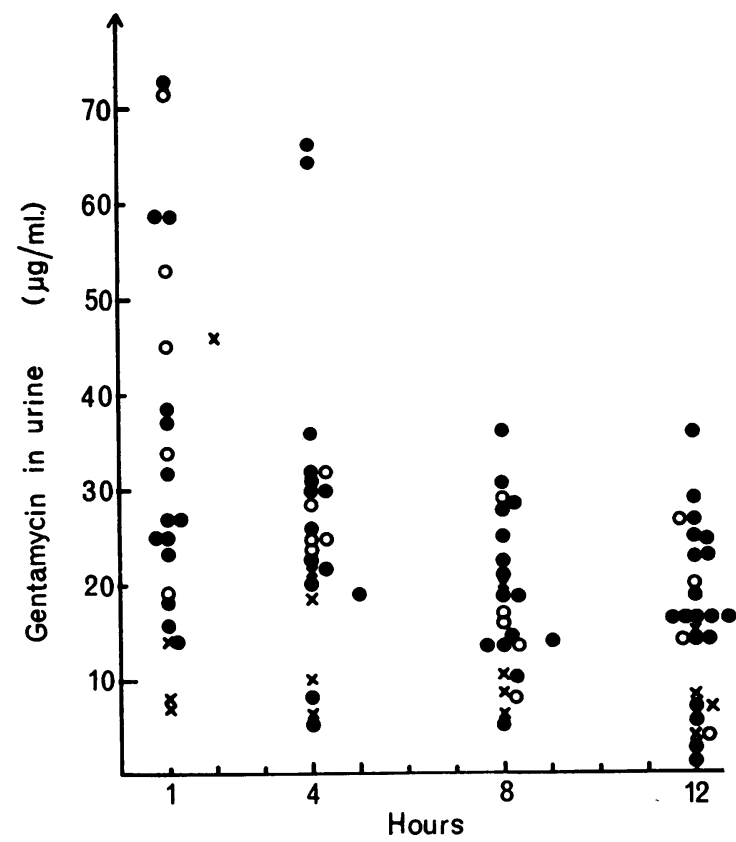

FIG. 3. Levels of gentamicin in urine of patients during the third day of treatment. Gentamicin was injected at 0 and $12 \mathrm{hr} . ; \bigcirc-\bigcirc$ patients with an endogenous creatinine clearance above $60 \mathrm{ml}$. per min.; -Oclearance value 20 to $60 \mathrm{ml}$. per min.; $\times-\times$ clearance value less than $20 \mathrm{ml}$. per min.

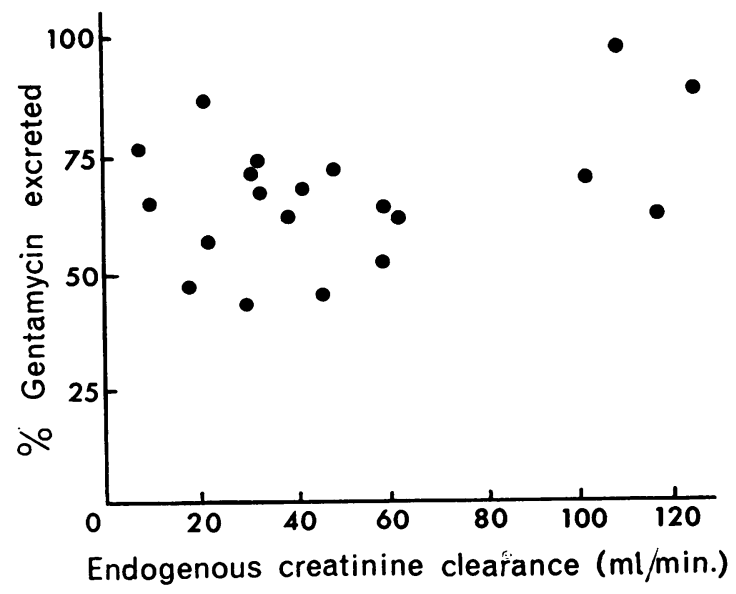

FIG. 4. Relation between the endogenous creatinine clearance and the percentage of active gentamicin excreted in the urine. Cases 4, 8,11, 14, and 17 are missing in the figure. active gentamicin in the urine was reached within one hour (Fig. 3). In group I the maximum value measured after one hour was $72 \mu \mathrm{g} . / \mathrm{ml}$., and the lowest value was $19 \mu \mathrm{g}$./ml. Four hours after injection the concentration varied between 24 and 32 $\mu \mathrm{g} . / \mathrm{ml}$., after eight hours between 8 and $29 \mu \mathrm{g} . / \mathrm{ml}$., and after 12 hours between 4 and $26 \mu \mathrm{g} . / \mathrm{ml}$.

In group II a maximum value of $73 \mu \mathrm{g}$. $/ \mathrm{ml}$. was reached after one hour; the lowest concentration was $14 \mu \mathrm{g} . / \mathrm{ml}$. After four hours the values varied between 5 and $66 \mu \mathrm{g} . / \mathrm{ml}$., after eight hours between 5 and $36 \mu \mathrm{g} . / \mathrm{ml}$., and after 12 hours between 1 and 36 $\mu \mathrm{g} . / \mathrm{ml}$.

In group III the highest value of $46 \mu \mathrm{g} . / \mathrm{ml}$. was measured two hours after injection; the one-hour value varied between 7 and $14 \mu \mathrm{g}$. $/ \mathrm{ml}$. After four hours the concentration was between 6 and $21 \mu \mathrm{g}$./ $\mathrm{ml}$. The corresponding value after eight hours was 6 and $20 \mu \mathrm{g} . / \mathrm{ml}$. and after 12 hours 4 and $15 \mu \mathrm{g} . / \mathrm{ml}$.

EXCRETION OF GENTAMICIN IN URINE RELATED TO KIDNEY FUNCTION The concentration of an antibiotic in the urine is, in addition to other factors, influenced by the volume of urine obtained from the patient, which therefore must be taken into consideration when estimating the amount of the given dose which is excreted in the urine. To eliminate this source of error the quantity of the given dose of gentamicin excreted in active form in the urine was plotted on the ordinate in Fig. 4 and the patient's endogenous creatinine clearance on the abscissa. Between $43 \%$ and $98 \%$ of the given dose was excreted in the urine in the active form. In group I the excretion varied between $62 \%$ and $98 \%$, in group II between $43 \%$ and $82 \%$, and in group III between $48 \%$ and $77 \%$.

CLINICAL RESULTS In 11 patients the pyelonephritis was complicated by either unilateral or bilateral calculus formation. Some of the relevant information concerning the patients is collected in Table III.

All the patients had negative urine cultures during treatment. Twelve of the 24 patients had negative urine cultures one to 14 months after the gentamicin treatment was stopped. The observation time for five of these patients (cases 18, 21, 22, 24, and 25) after the termination of treatment was only one to two months; the remaining seven patients had observation times exceeding five months. In one of these seven patients (case 3) positive urine cultures were found again after eight months; the patient's original Klebsiella strain was replaced by an $E$. coli strain.

Twelve of the patients relapsed. The period of time before positive urine cultures were found again varied between two days and four months. In nine 
of the patients the relapse was caused by the original strain, presumed only by a comparison of the antibiograms of the strains belonging to the same species isolated before gentamicin treatment and after relapse. In one patient (case 5) the original Klebsiella strain was replaced by a mixed flora of $E$. coli and Streptococcus faecalis; and in another patient (case 11) the Klebsiella strain was replaced by an Alkaligenes faecalis strain.

According to the in vitro test the average serum levels after one hour did not exceed the concentration necessary to inhibit the isolated bacteria at $p \mathrm{H} \mathrm{7 \cdot 4}$. The gentamicin concentration in the urine, however, stayed above the M.I.C. value in all the patients during the entire period of treatment. The concentration exceeded the corresponding M.B.C. value in 17 of the 19 patients where the M.I.C. and M.B.C. values had been determined. With the two patients (cases 2 and 12) in whom the M.B.C. concentration in the urine was not reached the results of treatment were good nevertheless, since both patients still had negative urine cultures after an observation time of 14 and nine months, respectively.

Case 8 , who was treated by haemodialysis, developed a Klebsiella sepsis. Gentamicin treatment was initiated in a dose high in proportion to the kidney function: $2.4 \mathrm{mg}$. $/ \mathrm{kg}$. bodyweight per day for the first day, then $1.2 \mathrm{mg}$. $/ \mathrm{kg}$. bodyweight per day during the next three days. The general condition of the patient improved dramatically by the first day and the blood cultures were negative.

\section{DISCUSSION}

The in vitro investigations showed that gentamicin had a broad spectrum against the majority of Gramnegative rods and Staphylococcus aureus. The average M.I.C. at $p \mathbf{H ~} 8.0$ for the 338 cultures investigated (Table I) was between 0.3 and 2.2 $\mu \mathrm{g} . / \mathrm{ml}$.; none required more than $40 \mu \mathrm{g}$. gentamicin/ $\mathrm{ml}$. The concentration necessary for bactericidal effects was about two to four times higher than that required for the inhibition of bacterial growth. Against $E$. coli and Klebsiella, gentamicin showed nearly the same in vitro activity as kanamycin and colistin (Table II). A comparison of the activity of these three antibiotics against Proteus species and Pseudomonas aeruginosa indicated that gentamicin was an effective agent against both species, whereas kanamycin was effective only against Proteus species and colistin only against Pseudomonas. The results obtained from the in vitro tests of the activity of gentamicin are in agreement with earlier reports (Black et al., 1963; Klein et al., 1964; Rubenis et al., 1963; Weinstein et al., 1963a, b).
The in vitro activity of gentamicin was greater in an alkaline than in an acid medium (Fig. 1). The concentration required for a bacteriostatic effect at pH 8 was from eight to 30 times lesser than that required at $p \mathrm{H}$ values from 5 to 7 . Similar results were obtained by Rubenis et al. (1963). It may be concluded from these facts that the treatment of urinary tract infections with gentamicin should be carried out with patients having an alkaline urine.

To eliminate the risk of toxic side effects, the dosage of gentamicin was determined individually for each patient with regard to kidney function (Table III). The serum concentration did not exceed 6.3 $\mu \mathrm{g} . / \mathrm{ml}$. in any patient even with the doubled dose of gentamicin (Fig. 2). After 12 hours only 0.1 to $2.5 \mu \mathrm{g}$. gentamicin $/ \mathrm{ml}$. serum was found. The maximum urine concentrations of gentamicin varied between 21 and $72 \mu \mathrm{g}$./ml. urine (Fig. 3). The concentration decreased relatively fast and after 12 hours between 4 and $26 \mu \mathrm{g}$. $/ \mathrm{ml}$. was found.

The excretion of active gentamicin in the urine varied between $43 \%$ and $98 \%$ of the given dose (Fig. 4). The highest excretion was reached in patients with normal kidney function and the lowest in a patient with renal insufficiency. No definite correlation could be found in this material between the patient's kidney function and the quantity of active gentamicin which was excreted. Bulger et al. (1963) reported $30 \%$ to $96 \%$ excretion of gentamicin in the urine. The high excretion of gentamicin in the urine also in patients with reduced renal function is of great importance in the treatment of patients with chronic urinary tract infections.

The first urine culture after initiation of the therapy was negative in all patients and 12 of the 24 patients still have negative cultures one to 14 months later (Table III). The cause of the relapse in 12 of the patients may be that this material consisted of patients with chronic pyelonephritis often complicated by, e.g., calculus (Table III). Before gentamicin therapy was initiated all the patients had been treated with a number of antibiotics and chemotherapeutics without lasting effects. Chronic urinary tract infections often recur after cessation of treatment, and as a rule only about $20 \%$ are cured (Kass, 1955; Grieble and Jackson, 1958; Turck, Browder, Lindemeyer, Brown, Anderson, and Petersdorf, 1962). In the report given more than $50 \%$ of the patients were cured. This may be due to the fact that on the sixth day of gentamicin therapy the patients were put on long-term treatment with either sulphonamides, nitrofurantoin, or acidifying agents (Table III).

No significant development of resistance to gentamicin of the bacteria which caused a relapse could be established. This observation differs from the experiences reported by Jao and Jackson (1963) 
who found a tendency towards increased resistance in vitro of the relapsing strain against gentamicin.

Serious toxic side effects in the form of irreversible labyrinth damage from gentamicin treatment were reported by Jao and Jackson (1963) and Bulger et al . (1963). Eleven of the patients in our study were carefully observed for ototoxic effects. One of them developed reversible labyrinthine damage after gentamicin treatment; this patient had a chronic pyelonephritis with an endogenous creatinine clearance of $17 \mathrm{ml} . / \mathrm{min}$. The dose of gentamicin was low, i.e., $0.4 \mathrm{mg}$. $/ \mathrm{kg}$. bodyweight per day. No other toxic manifestations have been observed.

\section{REFERENCES}

Black, J., Calesnick, B., Williams, D., and Weinstein, M. J. (1963). Antimicrob. A gents Chemother., 3, 138.
Bulger, R. J., Sidell, S., and Kirby, W. M. M. (1963). Ann. intern. Med., 59, 593.

Grieble, H. G., and Jackson, G. G. (1958). New Engl.J. Med., 258, 1. Jao, R. L., and Jackson, G. G. (1963). Antimicrob. A gents Chemother. $2,148$.

Kass, E. H. (1955). Amer. J. Med., 18, 764.

Klein, J. O., Eickhoff, T. C., and Finland, M. (1964). Amer. J. med. Sci., 248, 528.

Luedemann, G. M., and Brodsky, B. C. (1963). Antimicrob. A gents Chemother., 3, 116.

Oden, E. N., Stander, H., and Weinstein, M. J. (1963). Ibid., 3, 8.

Rosselet, J. P., Marquez, J., Meseck, E., Murawski, A., Hamdan, A., Joyner, C., Schmidt, R., Migliore, D., and Herzog, H. L. (1963). Ibid., 3, 14.

Rubenis, M., Kozij, V. M., and Jackson, G. G. (1963). Ibid., 3, 153.

Turck, M., Browder, Ann A., Lindemeyer, R. I., Brown, N. K., Anderson, K. N., and Petersdorf, R. G. (1962). New Engl. J. Med., 267, 999.

Weinstein, M. J., Luedemann, G. M., Oden, E. M., and Wagman, G. H. (1963a). Antimicrob. A gents Chemother., 3, 1.

,,$-- \ldots$, Rosselet, J. P., Marquez, J. A., Coniglio, C. T., Charney, W., Herzog, H. L., and Black, J. (1963b). J. med. Chem., 6, 463. 